\title{
Comparing Use Terms in Spanish and US Research University E-journal Licenses: Recent Trends
}

\section{Juan-Carlos Fernández-Molina, Kristin R. Eschenfelder, and Alan P. Rubel}

\begin{abstract}
This paper describes the results of a study to compare contemporary e-journal licenses from two research universities in the United States and Spain in terms of e-reserves, interlibrary loan, text and data mining, authors' rights and treatment of copyright exceptions, usage statistics, governing law, data privacy, and obligations entailing security. The data include a higher proportion of scholarly society and academic press publishers than earlier license analyses. This analysis compares license terms over time, across publisher types and between the two libraries, and it compares findings with recommendations from model licenses. The results show progress toward model license goals in some areas, but deficiencies in others including self-archiving, usage statistics clauses, and clauses related to e-resource data privacy and library security and disciplinary obligations. Our findings also raise questions about international ILL and governing venue clauses in library licenses outside the North American context.
\end{abstract}

\section{Introduction}

In the digital setting, licenses for information sources (journals, e-books, databases) have replaced sales as the most common means of obtaining access. This situation presents advantages and disadvantages. Among the former, upheld as particularly advantageous by the representatives of the academic publishing sector, are the flexibility to arrive at agreements acceptable to both parties involved, and their adaptability to an ever-changing environment, alleviating the inevitable problems of copyright law to update as quickly as required. Also important, however, are the disadvantages - license terms may weaken or nullify end user and library exceptions to copyright law. In most jurisdictions, what is laid out in a contract prevails over exceptions provided for by copyright law. ${ }^{1}$

Unfortunately, the application of this general principle of freedom of contract is only positive if there is an adequate balance between the two negotiating parties, something that is not normally the case with licenses for digital resources. They are usually contracts with a standard, predetermined content. Even when there is, in theory, a possibility to negotiate the terms and

Juan-Carlos Fernández-Molina is a Professor in the Department of Information and Communication Studies at the University of Granada, Spain; e-mail: jcfernan@ugr.es. Kristin R. Eschenfelder is a Professor in the Information School at the University of Wisconsin-Madison; e-mail: eschenfelder@wisc.edu. Alan Rubel is an Associate Professor in the Information School at the University of Wisconsin-Madison; e-mail: arubel@wisc.edu. () 2021 Juan-Carlos Fernández-Molina, Kristin R. Eschenfelder, and Alan P. Rubel, Attribution-NonCommercial (https:// creativecommons.org/licenses/by-nc/4.0/) CC BY-NC. 
conditions, in practice this is complicated by the tremendous difference in negotiating power between publishers and users. Past studies have shown it is not unusual for academic libraries to sign licenses with clauses that impede both end user and library rights granted by copyright law. ${ }^{2}$ Model licenses, such as those from Liblicense and the California Digital Library (CDL) Model License, provide a template that librarians can use in developing licenses, also serving as a statement about what license terms are acceptable to the library community. ${ }^{3}$ Yet libraries are not always able to implement them because the scholarly publications market functions as an oligopoly, dominated by a few major publishers that control content. For example, more than 50 percent of the articles registered in the Web of Science appear in journals owned by one of the five largest publishing houses (Elsevier, Springer, Wiley, Taylor \& Francis, Sage). The figure is more than 70 percent in the realm of the social sciences. ${ }^{4}$

In the face of these concerns about licensing, our study has two objectives. One is to appraise to what extent license terms have changed in comparison to model license suggestions and the findings from prior licensing studies. The second goal is to examine international differences in licenses, and especially to confirm if any effect on the contents of the licenses may be traced to the fact that we are dealing with countries having two different legal traditions: Common Law (USA) and Civil Law (Spain). In the latter, the exceptions and limitations to copyright conform a closed list with a series of strict criteria and circumstances that must be given for their application. On the contrary, in Common Law countries there is an "umbrella" exception, fair use/dealing.

We obtained licenses from two different research universities on opposite sides of the Atlantic - one in the USA and one in Spain. Both institutions are large public universities with a full-time enrollment of more than 40,000 students each. Both offer a variety of academic and professional programs, so that their libraries subscribe to a wide array of electronic journals and other resources. We analyze license terms related to eight areas: electronic reserves (ereserves), interlibrary loan, text and data mining, authors' rights, usage statistics, governing law, data privacy, and obligations entailing security.

\section{Literature Review}

Below we review research into license terms related to each area of our analysis. Given the goal of our paper, we focus on studies examining license terms regardless of whether those licenses are signed or publisher boilerplate licenses. Because of the changing nature of license terms, we focus primarily on studies published in 2010 or later.

One issue of continuing importance in licensing, especially given the growth of online higher education, is that of terms related to electronic reserves (e-reserves). Studies examining librarian perceptions of e-reserves policies or e-reserves practices in different libraries are prevalent, but fewer studies have examined license terms. ${ }^{5}$ Prior work has shown that most licenses allow e-reserves, but with limitations. For example, in one examination of e-reserve terms in 224 licenses from 11 publishers, Eschenfelder found 26 percent of licenses required deletion of the file at the end of use and 47 percent allowed linking to articles. She found commercial publishers' licenses were more likely to require deletions, but also more likely to permit linking. ${ }^{6}$

Interlibrary loan is a frequent focus of licensing scholarship because the license operates like a gatekeeper that can halt any ILL petition. ${ }^{7}$ ILL license terms may restrict the type of receiving library (for example, no commercial institutions), limit ILL to one nation (for instance, 
same nation as sending library only), or define the procedure through which the copy should be sent to the receiving library (such as requiring that a paper copy be printed and then faxed/ scanned), and how it may be delivered to the ultimate user (example: paper only). Further, ILL staff may not know whether a specific journal or publisher permits ILL. ${ }^{8}$ Past studies of license terms suggest that outright prohibition of ILL is rare, but other restrictions are still common. For example, Wiley's 2004 survey of ILL staff in 13 libraries reported restrictions on electronic delivery, as well as delivery to commercial or for-profit libraries. ${ }^{9}$ Lamaroux and Stemper's 2011 review of 241 licenses at University of Minnesota and 80 licenses at North Carolina State suggested that prohibition of ILL was rare, but more likely to occur among small society publishers, and that print requirements for transmission were still common..$^{10}$ Tiessen's 2012 review of 72 licenses at University of Calgary confirms that some licenses banned digital transmission, some required print copies as part of transmission, and at least one license did not allow transmission outside Canada. ${ }^{11}$ The 2013 study from Eschenfelder et al. found ILL restrictions were common: 64 percent of 2006-2009 licenses did not allow ILL to commercial users, and 79 percent required printing as part of the ILL process. The authors found only 59.5 percent permitted e-transmission, around 40 percent arguably still requiring paper or fax transmittal. Eschenfelder furthermore found that, while commercial publisher licenses were more likely to include a print requirement, they were also more likely to permit secure e-transmission. Noncommercial publisher licenses tended to restrict ILL to commercial/for-profit libraries. ${ }^{12}$

A newer issue is text and data mining of licensed databases. ${ }^{13}$ In one prior study of how licenses address text and data mining, Grewal and Huhn analyzed 32 signed licenses from Concordia University. They found that, even though 47 percent explicitly allowed data and text mining activities, an equal proportion (47\%) did not address it at all. A small portion of licenses $(6 \%)$ forbade it. ${ }^{14}$ Professional conference presentations suggest that permissions for text and data mining might be handled outside the formal license, via addenda or other side agreements. ${ }^{15}$

Many urge inclusion of language guaranteeing authors' rights to self-archive to promote open science and greater access to scholarly information. ${ }^{16}$ Model licenses urge inclusion of self-archiving terms. We found few examples of analysis of self-archiving license terms in the professional literature. In one small study in 2018, Singh and Mukherjee examined boilerplate licenses from five major commercial publishers and concluded that self-archiving language was not included. ${ }^{17}$ Other studies of self-archiving employ sources of data about authors' rights such as the SHERPA/ROMEO database of publisher copyright and self-archiving policies, which collects policies at the publisher and journal level.

Usage statistics are important for understanding the value of an electronic resource. Model licenses, or the International Coalition of Library Consortia (ICOLC), urge inclusion of terms guaranteeing usage statistics. Project COUNTER is an effort to make statistics uniform, and it is also a registry of COUNTER-compliant publishers. Although many articles discuss the value of usage statistics, or how to use them in decision making, few examine license treatment of usage statistics. In one study, Rubel and Zhang examined 42 licenses from 11 different publishers. They found that 64.3 percent of their licenses specified that publishers provide a licensee with usage data, and 21.4 percent of their licenses stated that the publisher would provide COUNTER-compliant use data. ${ }^{18}$

Library licensing experts advise libraries to make certain the license is governed by the law and courts of the library's home institution location or, if this is not possible, to remain 
silent on the issue. ${ }^{19}$ While governing law and venue are widely discussed in licensing how-to manuals, we were unable to find prior work that systematically analyzed license text for the treatment of governing law and venue.

Licenses typically include clauses about data sharing that may impact patron data privacy. They also now typically include terms that place security obligations on libraries to monitor for breaches of licensed resources. Magi examined the privacy policies of one library's publishers and found that most failed to meet the privacy-protection expectations suggested by library professional codes of conduct. ${ }^{20}$ In their analysis of the privacy and security clauses of 42 licenses from 11 publishers, Rubel and Zhang found that two-thirds specified publishers could collect non-IP information about use. They report that 33 percent of licenses contained terms about publishers sharing data with third parties, and only one of the 42 licenses examined required third parties to comply with the confidentiality provisions of the license. ${ }^{21}$

The security of licensed resources is a concern, and licenses may include obligations for libraries to notify publishers of breaches, to protect against unauthorized use, to block access of authorized users found to be in breach of terms of use, and even to take disciplinary action against those users. In Rubel and Zhang's license study, a substantial majority of licenses (81\%) required libraries to notify publishers when they learned of unauthorized use. Further, 38 percent required libraries to monitor for unauthorized use. Nearly one in $10(9.5 \%)$ of the licenses allowed the publisher to suspend authorized user access, and 16.7 percent allowed the publisher to suspend access based on IP address. Overall, 42.9 percent of the licenses required libraries to take unspecified "disciplinary action" when they learned of unauthorized use. ${ }^{22}$

\section{Methodology}

In the autumn of 2016, we solicited the participation of two large university libraries, one in Spain and one in the United States. In both cases, we sought permission from the head of collection development to gain access to the desired licenses. Our request was limited to publisher products to which both universities subscribed to obtain a matching set of signed licenses. Because prior licensing work has included fewer analyses of society and academic press publishers, we specifically sought to obtain licenses from those publisher types, as well as common commercial publishers. The library of the US university referred us to a consortium that had signed three of the licenses at the consortial level (Sage, Springer, and Wiley).

We gathered 36 paired licenses, that is, 18 specific publishers from each university. This included four pairs of matched university press licenses, six pairs of society press matched licenses, and eight pairs of commercial licenses. Confidentiality clauses were an issue. In many cases, the universities had not signed a confidentiality clause and provided the license with just names and total prices obscured. But, in other cases, the library would only provide portions of licenses that the confidentiality clause did not restrict; luckily, in these cases, the terms of use sections were typically available. We were unable to obtain a recent Elsevier signed license from the US university due to confidentiality clauses. Another issue that emerged was the age of the licenses. License terms change over time, and older licenses may not reflect changing norms or terms for new uses such as data mining. But university libraries may not seek to update older licenses for a variety of reasons including a preference for updating terms with addenda, or concerns that reopening negotiations may lead to a loss of preferred terms. Most of the licenses we obtained were signed after 2010, though our data do contain a few 
older licenses. In instances of incomplete or old licenses, we supplemented what we received with the publishers' most recent posted English language "boilerplate" license. In instances where the newer boilerplate license terms were different, we used the newer terms because of our interest in describing contemporary terms. All but one of the licenses obtained were in English; one from the Spanish university was in Spanish.

To analyze the licenses, we created a codebook drawing on codebooks used by prior studies of licenses. ${ }^{23}$ We added new questions from the November 2014 version of the Liblicense model license related to these issues: 1) potential diminution of copyright-related rights and privileges of the licensee or authorized users by the license; 2) authors' rights related to open access and digital repositories; and 3) rights for text and data mining activities. We also included questions about governing law and venue.

The codebook contained yes/no questions answered with a " 1 " for yes and a " 0 " for no. Each question had accompanying coding rules to guide responses (see appendix A for copy of codebook and coding rules). All three authors had prior experience analyzing e-journal and e-book licenses. Coder training involved coding a series of boilerplate licenses collected for a different study to ensure agreement on coding rules and procedures.

Two of the authors coded each license independently, marking answers on a coding spreadsheet. The second author compared the separate analysis and noted any differences. The intercoder reliability (ICR) score was calculated at the question level. We employed a percent agreement ICR calculation that counts the number of times the coders agreed on a question and divides it by the total number of possible scores for that question. ICR scores in licensing analysis can be interpreted as the degree to which two coders interpret the license clause the same way. As recommended by content analysis methodology sources, we report the ICR score for each question separately rather than lumping all questions together, so that readers can spot areas of difficulty.

In licensing analysis, ICR scores vary based on error and license clause vagueness. In terms of error, coding scores may differ because coders are not paying close enough attention or because they simply write down the wrong number. In such cases, joint review and discussion of discrepancies can remedy errors and provide a reliable final score. Yet, in licensing analysis, coders may give different scores because license clauses are (often intentionally) vague, and reasonable people might interpret the license clause differently. In these cases, a lower ICR score is an indicator of license term vagueness.

To ensure quality and to separate any errors from indicators of vague license clauses, we tracked the ICR for each question in our analysis. In most instances where we saw discrepancies in our initial analysis, the coding differences resulted from simple coding errors. In these cases, we discussed the discrepancies and easily agreed upon a final reported score. But for some questions related to value license clauses (such as questions related to security), disagreement stemmed from vagueness about what the license required. We had set a goal of achieving an 80 percent or higher ICR agreement on all questions reflecting a typical measure of ICR reliability. In most cases, results were much better-the majority of our questions had a final agreement of 85 percent or more. In a few areas, however, we confronted license term vagueness, and we disagreed about how to interpret the term, even after review and discussion. In these instances, the first author made the final reported coding decision; still, we reported the lower ICR score resulting from the vagueness. These difficulties are described below in the Results section. 


\section{Results}

\section{License Demographics}

Appendix B summarizes our data set by the three publisher types: society, academic press, and commercial publishers. Within each group, table 1 lists the publisher name, the year the license was signed (or if it is a publisher boilerplate), and whether it stemmed from the US or Spanish university library. Despite our intention to obtain all newer licenses, there were five signed in 2009 or earlier (two from Spain, three from the US). For these five cases, we compared our data with newer terms available on publisher websites, and the differences, where applicable, were noted in the results. We received 11 licenses signed from 2010 through 2013 (four from Spain and seven from the US), and 20 licenses signed in 2014 or later (12 Spanish and eight from the US).

\section{Electronic Reserves}

Results (see table 1) confirm that permitting e-reserves is a norm but that restrictions on ereserves remain. These include requirements to delete a work at the end of a semester or use period and permissions related to linking to articles. For example, 36 percent of our licenses require deletion of a work; this is an increase from earlier studies in which 26 percent of licenses included the limitation. ${ }^{24}$ The rise in the proportion of licenses requiring deletion that we found may stem from the inclusion of more society and academic press licenses in this study's sample, which points to our second important contribution. Looking by publisher

\begin{tabular}{|c|c|c|}
\hline \multicolumn{3}{|c|}{$\begin{array}{l}\text { TABLE } 1 \\
\text { E-Reserves/Course Packs and Licenses by Type and Nation }\end{array}$} \\
\hline $\begin{array}{l}\text { Question } \\
\text { All Licenses N = } 36\end{array}$ & $\begin{array}{l}\text { Number by Publisher Type } \\
\text { Society: } 12 \\
\text { University: } 8 \\
\text { Commercial: } 16\end{array}$ & $\begin{array}{l}\text { Spanish }(n=18) \\
\text { US Licenses }(n=18)\end{array}$ \\
\hline \multirow{3}{*}{$\begin{array}{l}\text { Q26: E-reserves/course } \\
\text { packs not permitted } \\
4 \text { out of } 36 \text { licenses }(11 \%)\end{array}$} & $\begin{array}{l}\text { Of the } 12 \text { society press licenses, } 0 \\
\text { included this term }\end{array}$ & \multirow{3}{*}{$\begin{array}{l}1 \text { of } 18 \text { Spanish licenses }(5 \%) \\
3(16 \%)\end{array}$} \\
\hline & $\begin{array}{l}\text { Of the } 8 \text { university press licenses, } 2 \\
\text { included this term (25\%) }\end{array}$ & \\
\hline & $\begin{array}{l}\text { Of the } 16 \text { commercial publisher } \\
\text { licenses, } 2 \text { included this term (13\%) }\end{array}$ & \\
\hline \multirow{3}{*}{$\begin{array}{l}\text { Q29: Requires deletion at } \\
\text { end of semester/course/ } \\
\text { use } \\
13 \text { out of } 36 \text { licenses or } \\
36 \%\end{array}$} & $\begin{array}{l}\text { Of the } 12 \text { society press licenses, } 9 \\
\text { included this term }(75 \%)\end{array}$ & \multirow{3}{*}{$\begin{array}{l}7 \text { of } 18 \text { Spanish licenses (39\%) } \\
6 \text { of } 18 \text { US licenses (33\%) }\end{array}$} \\
\hline & $\begin{array}{l}\text { Of the } 8 \text { university press licenses, } 4 \\
\text { included this term (50\%) }\end{array}$ & \\
\hline & $\begin{array}{l}\text { Of the } 16 \text { commercial publisher } \\
\text { licenses, } 0 \text { included this term }\end{array}$ & \\
\hline \multirow{3}{*}{$\begin{array}{l}\text { Q30: Permits a link to the } \\
\text { article in the database } \\
7 \text { out of } 36 \text { licenses (19\%) }\end{array}$} & $\begin{array}{l}\text { Of the } 12 \text { society press licenses none } \\
\text { included this term }\end{array}$ & \multirow{3}{*}{$\begin{array}{l}5 \text { of } 18 \text { Spanish licenses (28\%) } \\
2 \text { of } 18 \text { US licenses ( } 11 \%)\end{array}$} \\
\hline & $\begin{array}{l}\text { Of the } 8 \text { university press licenses, } 2 \\
\text { included this term (25\%) }\end{array}$ & \\
\hline & $\begin{array}{l}\text { Of the } 16 \text { commercial publisher } \\
\text { licenses, } 5 \text { included this term (31\%) }\end{array}$ & \\
\hline
\end{tabular}


type, data show important differences: no commercial publishers required deletion, but 75 percent of society publisher licenses and 50 percent of university press licenses required deletion. This is a change from earlier study results in which commercial publishers' licenses were more likely to require deletions. ${ }^{25}$ Another finding we observed was the disappearance of clauses explicitly permitting linking. The proportion of licenses explicitly permitting a link to articles in a licensed database was lower (19\%) than in older research, which reported 47 percent of licenses including linking permission clauses. More Spanish university licenses contained terms permitting linking ( $28 \%$ vs US $11 \%)$.

\section{Interlibrary Loan}

Our study confirms prior work showing that most licenses permit ILL but that ILL limitations persist. This includes prohibitions on ILL for commercial users, print requirements, and limitations on international delivery. Our data (see table 2) suggest no change to prohibitions on delivery to commercial users compared to earlier studies. More than half (61\%)

\begin{tabular}{|c|c|c|}
\hline \multicolumn{3}{|c|}{$\begin{array}{c}\text { TABLE } 2 \\
\text { Interlibrary Loan and Licenses by Type and Nation }\end{array}$} \\
\hline $\begin{array}{l}\text { Question } \\
\text { All Licenses N = } 36\end{array}$ & $\begin{array}{l}\text { Number by Publisher Type } \\
\text { Society: } 12 \\
\text { University: } 8 \\
\text { Commercial: } 16\end{array}$ & $\begin{array}{l}\text { Spanish }(n=18) \\
\text { US Licenses }(n=18)\end{array}$ \\
\hline \multirow{3}{*}{$\begin{array}{l}\text { Q35/36: Secure e-transmission } \\
\text { permitted/required: } \\
21 \text { out of } 36 \text { licenses ( } 58 \%)\end{array}$} & $\begin{array}{l}\text { Of the } 12 \text { society press licenses, } 7 \text { included } \\
\text { this term (58\%) }\end{array}$ & \multirow{3}{*}{$\begin{array}{l}\begin{array}{l}11 \text { of } 18 \text { Spanish licenses } \\
(63 \%)\end{array} \\
8 \text { of } 18 \text { US licenses }(44 \%)\end{array}$} \\
\hline & $\begin{array}{l}\text { Of the } 8 \text { university press licenses, } 4 \\
\text { included this term (50\%) }\end{array}$ & \\
\hline & $\begin{array}{l}\text { Of the } 16 \text { commercial publisher licenses, } 10 \\
\text { included this term (63\%) }\end{array}$ & \\
\hline \multirow{3}{*}{$\begin{array}{l}\text { Q37: No sending to } \\
\text { commercial users } \\
22 \text { out of } 36 \text { licenses }(61 \%)\end{array}$} & $\begin{array}{l}\text { Of the } 12 \text { society press licenses, } 8 \text { included } \\
\text { this term }(67 \%)\end{array}$ & \multirow{3}{*}{$\begin{array}{l}\begin{array}{l}13 \text { of } 18 \text { Spanish licenses } \\
(59 \%)\end{array} \\
10 \text { of } 18 \text { US licenses }(55 \%)\end{array}$} \\
\hline & $\begin{array}{l}\text { Of the } 8 \text { university press licenses, } 3 \\
\text { included this term (38\%) }\end{array}$ & \\
\hline & $\begin{array}{l}\text { Of the } 16 \text { commercial publisher licenses, } 12 \\
\text { included this term (75\%) }\end{array}$ & \\
\hline \multirow[t]{3}{*}{$\begin{array}{l}\text { Q34: Printing required as part } \\
\text { of ILL process }\end{array}$} & $\begin{array}{l}\text { Of the } 12 \text { society press licenses, } 5 \text { included } \\
\text { this term (42\%) }\end{array}$ & \multirow{3}{*}{\begin{tabular}{|l}
$\begin{array}{l}11 \text { of } 18 \text { Spanish licenses } \\
(61 \%)\end{array}$ \\
2 of 18 US licenses $(11 \%)$
\end{tabular}} \\
\hline & $\begin{array}{l}\text { Of the } 8 \text { university press licenses, } 3 \\
\text { included this term (38\%) }\end{array}$ & \\
\hline & $\begin{array}{l}\text { Of the } 16 \text { commercial publisher licenses, } 5 \\
\text { included this term (31\%) }\end{array}$ & \\
\hline \multirow{3}{*}{$\begin{array}{l}\text { Q39: Receiving institution } \\
\text { must be in the same country } \\
\text { as the subscriber }\end{array}$} & $\begin{array}{l}\text { Of the } 12 \text { society press licenses, } 4 \text { included } \\
\text { this term (33\%) }\end{array}$ & \multirow{3}{*}{$\begin{array}{l}\begin{array}{l}6 \text { of } 18 \text { Spanish licenses } \\
(33 \%)\end{array} \\
3 \text { of } 18 \text { US licenses }(17 \%)\end{array}$} \\
\hline & $\begin{array}{l}\text { Of the } 8 \text { university press licenses, } 2 \\
\text { included this term (25\%) }\end{array}$ & \\
\hline & $\begin{array}{l}\text { Of the } 16 \text { commercial publisher licenses, } 3 \\
\text { included this term (19\%) }\end{array}$ & \\
\hline
\end{tabular}


of our licenses prohibited commercial users (ICR 89\%), but that percentage increases to 70 percent if you consider only our post-2014 licenses. Our data show that a higher proportion of commercial publisher licenses $(75 \%)$ included this restriction, followed closely by society publisher licenses (67\%). In comparison, only 38 percent of university press licenses restricted ILL to commercial users.

The second most common limitation ( $36 \%$ of our sample) was the requirement that the ILL process include a printed copy (that is, sending printed copies via mail, printing a copy to fax or send via other secure methods, or requiring that the receiving institution deliver the material in print only) (ICR 83\%). Compared to earlier studies, the proportion of licenses requiring printing as part of the ILL process has fallen from the 79 percent reported in older studies to the 36 percent of this study's data. ${ }^{26}$ The striking exception is that 61 percent of the Spanish licenses included the print requirement, whereas only $11 \%$ of US licenses contained it. Finally, a quarter of our licenses $(25 \%)$ included a requirement that the receiving institutions be located in the same country as the provider (ICR 100\%). We found a greater proportion of the Spanish university licenses contained this restriction (33\% Spain and 16\% US). This limitation on cross-border information impedes flows between Spain and other countries. Our data are too limited to make broad claims, but our results suggest a strong need to examine the prevalence of international ILL restrictions in licenses signed by non-North American academic libraries.

\section{Text and Data Mining}

Similar to Grewal and Huhn's findings, only a small number (3) of our licenses addressed text mining (97\% ICR). ${ }^{27}$ No licenses in our sample prohibited it. Two licenses included clauses permitting it, as long as it was noncommercial. Two licenses included limitations on distributing the results of text mining. The age of our licenses may contribute to the finding: the three licenses addressing it were from 2015 and 2018 (Elsevier Spain 2015; Oxford University Press Spain 2015; Taylor \& Francis US 2018 boilerplate). Our older licenses would be less likely to discuss text mining because its application to publisher corpuses is relatively new. The lack of information may also be because libraries and publishers manage text mining in separate agreements or addendums. It is desirable that licenses include clauses in which this type of activity is expressly allowed so that researchers can develop their text and data mining activities without uncertainty regarding infringement of the law. The new European directive signals the way forward, since it establishes a right to carry out these activities that cannot be canceled by contract. ${ }^{28}$

\section{Authors' Rights and License Treatment of Copyright Exceptions}

We examined the degree to which each license explicitly allowed self-archiving on personal web pages, institutional repositories, or third-party repositories $(97 \%, 100 \%$ and $97 \%$ ICR, respectively). We found three licenses that permitted any type of self-archiving: two from Spain and one from the US. While just a few licenses included self-archiving rights language suggested by Liblicense and other model licenses, an earlier 2018 examination of commercial licenses found none. ${ }^{29}$

We also examined licenses to see whether they addressed the relationship between the license and any of the copyright exceptions and privileges in favor of libraries or their users. We encountered six licenses stating that the license shall not restrict acts otherwise 
permitted under copyright law (92\% ICR). Only two licenses were found to include a clause specifying that the license cannot impose additional restrictions over content in the public domain or that was issued under an open license. Because the UK copyright law of 2014 established the nullity of clauses that would limit copyright exceptions, we were curious to see if more publishers might include this language after 2014. Unfortunately, most of our examples of licenses that addressed this issue predate the UK law. Cambridge University Press and Taylor and Francis were examples of UK publishers whose licenses did include the language.

\section{Usage Statistics}

We examined license language related to usage statistics (Table 3). Only $50 \%$ of our licenses specified that the publisher would provide usage statistics (ICR 92\%). Comparing our results to earlier work shows a decrease in the proportion of licenses including recommended usage statistics licensing terms. Rubel and Zhang found a greater proportion of licenses (64.3\%) promising provision of usage data to licensees. ${ }^{30}$ But in the earlier work only $21 \%$ stipulated that the data would be COUNTER-compliant, while our study found a larger proportion (33\% with ICR 94\%). Comparing US and Spain, we found that a higher proportion of licenses from the Spanish university pledged to provide usage statistics (61\% vs 39\%). One explanation could be that US-based librarians and publishers do not include those term in licenses because publisher compliance with COUNTER standards is now advertised and tracked via the COUNTER registry. To test this assumption, we compared our list of publishers to the projectcounter.org registry database. We found that many publishers included in the COUNTER registry did not include pledges of COUNTER-compliant statistics in their licenses. The Liblicense model still recommends inclusion of usage terms in the license.

\begin{tabular}{|c|c|c|}
\hline \multicolumn{3}{|c|}{$\begin{array}{l}\text { TABLE } 3 \\
\text { Usage Statistics and Licenses by Type and Nation }\end{array}$} \\
\hline Question & $\begin{array}{l}\text { Number by Publisher Type } \\
\text { Society: } 12 \\
\text { University: } 8 \\
\text { Commercial: } 16\end{array}$ & $\begin{array}{l}\text { Spanish }(n=18) \text { US } \\
\text { Licenses }(n=18)\end{array}$ \\
\hline \multirow{3}{*}{$\begin{array}{l}\text { Q40: The publisher will } \\
\text { provide usage data to } \\
\text { licensee }\end{array}$} & $\begin{array}{l}\text { Of the } 12 \text { society press licenses, } 5 \text { included } \\
\text { this term }(42 \%)\end{array}$ & \multirow{3}{*}{$\begin{array}{l}11 \text { of } 18 \text { Spanish licenses } \\
(61 \%) \\
7 \text { of } 18 \text { US licenses (39\%) }\end{array}$} \\
\hline & $\begin{array}{l}\text { Of the } 8 \text { university press licenses, } 4 \text { included } \\
\text { this term }(50 \%)\end{array}$ & \\
\hline & $\begin{array}{l}\text { Of the } 16 \text { commercial publisher licenses, } 9 \\
\text { included this term (56\%) }\end{array}$ & \\
\hline \multirow{3}{*}{$\begin{array}{l}\text { Q41: The usage data provided } \\
\text { should be COUNTER- } \\
\text { compliant } \\
12 \text { of } 36 \text { licenses }(33 \%)\end{array}$} & $\begin{array}{l}\text { Of the } 12 \text { society press licenses, } 4 \text { included } \\
\text { this term }(33 \%)\end{array}$ & \multirow{3}{*}{$\begin{array}{l}7 \text { of } 18 \text { Spanish licenses } \\
(39 \%) \\
5 \text { of } 18 \text { US licenses (28\%) }\end{array}$} \\
\hline & $\begin{array}{l}\text { Of the } 8 \text { university press licenses, } 3 \text { included } \\
\text { this term }(38 \%)\end{array}$ & \\
\hline & $\begin{array}{l}\text { Of the } 16 \text { commercial publisher licenses, } 5 \\
\text { included this term (31\%) }\end{array}$ & \\
\hline
\end{tabular}




\section{Governing Law and Venue}

Our analysis of governing law and venue focused on claims made in the license about which nation's law would govern. Most of the Spanish university licenses (13 of 18) required a nonSpanish governing law and venue. Analysis of the US licenses is less interesting, as most major publishers have US legal offices and a US-based legal venue is typical. Within the United States, negotiations about governing law and venue have more to do with states and applicable state law; nonetheless, we did not analyze the US data at the state level. ${ }^{31}$

The high proportion of licenses from the Spanish university requiring non-Spanish governing law and venue does not comport with resources like the IFLA E-Resource Collection Development Guide, which state that disputes should be arbitrated in the library's home legal venue. $^{32}$ The failure to ensure Spanish governing law and venue for the Spanish university licenses has important practical implications. In the event of a conflict, the Spanish university would find it more difficult and expensive to defend its interests in a foreign court. While the publisher boilerplate typically includes the home jurisdiction of the publisher for governing law and venue, these terms are subject to negotiation. Further research would do well to examine a wider sample of non-North American signed licenses to see if this finding is common beyond our Spanish university realm.

\section{Data Privacy}

We examined the licenses to see if they contained terms about publishers sharing usage data with third parties. Only 19 percent of our licenses included this provision (ICR 97\%), and they tended to be newer, commercial, or university press licenses from the Spanish university. Comparing our data to the earlier Rubel and Zhang findings on data privacy, a lower proportion of our licenses address third-party sharing (19\% vs 33\%). ${ }^{33}$ One explanation is that this study included 12 society publisher licenses (six pairs), whereas the earlier work included only one. Our data show that society publisher licenses were less likely ( $8 \%)$ than university or commercial publisher licenses (both 25\%) to include a clause addressing third-party sharing.

We also looked for language obligating third-party data users to comply with the confidentiality provisions of the license. We found only one license that contained this type of assurance (ICR 97\%).

\section{Security Rights Reserved by Publisher}

Upon examining whether the licenses reserved rights for the publisher to take action to terminate authorized users' access in case of a breach, we found (see table 4) that 56 percent of our licenses indeed included such terms. This is a noteworthy increase from the 9.5 percent found in Rubel and Zhang's 2007-2009 license set, again suggesting that more licenses are coming to include this requirement. ${ }^{34}$ We moreover found that, in 28 percent of our licenses, publishers reserved the right to suspend an IP address in case of a breach (ICR for both 83\%) compared to the 16.7 percent found by Rubel and Zhang's study. Analyzing the data by publisher type, we found commercial publishers' licenses were most likely to reserve the publisher's right to suspend authorized user access $(69 \%)$, followed by university press publishers $(50 \%)$ and society publishers $(42 \%)$. A greater proportion of the Spanish university licenses contained clauses reserving publishers' rights to suspend user access (72\%) as compared to the US university licenses (39\%). 


\begin{tabular}{|c|c|c|}
\hline \multicolumn{3}{|c|}{$\begin{array}{c}\text { TABLE } 4 \\
\text { Breach Action and Licenses by Type and Nation }\end{array}$} \\
\hline $\begin{array}{l}\text { License Contains Terms } \\
\text { Reserving Right for Publisher } \\
\text { to: }\end{array}$ & $\begin{array}{l}\text { Number by Publisher Type } \\
\text { Society: } 12 \\
\text { University: } 8 \\
\text { Commercial: } 16\end{array}$ & $\begin{array}{l}\text { Spanish }(n=18) \\
\text { US Licenses }(n=18)\end{array}$ \\
\hline \multirow{2}{*}{$\begin{array}{l}\text { Q45: Suspend authorized user } \\
\text { access based on failure to abide } \\
\text { by license terms }\end{array}$} & $\begin{array}{l}\text { Of the } 12 \text { society press licenses, } 5 \\
\text { included this term ( } 42 \%)\end{array}$ & \multirow{3}{*}{$\begin{array}{l}13 \text { of } 18 \text { Spanish licenses } \\
(72 \%) \\
7 \text { of } 18 \text { US licenses (39\%) }\end{array}$} \\
\hline & $\begin{array}{l}\text { Of the } 8 \text { university press licenses, } 4 \\
\text { included this term (50\%) }\end{array}$ & \\
\hline 20 of 36 licenses (56\%) & $\begin{array}{l}\text { Of the } 16 \text { commercial publisher } \\
\text { licenses, } 11 \text { included this term (69\%) }\end{array}$ & \\
\hline \multirow{3}{*}{$\begin{array}{l}\text { Q46: Suspend access of the } \\
\text { IP address(es) from which the } \\
\text { unauthorized use occurred }\end{array}$} & $\begin{array}{l}\text { Of the } 12 \text { society press licenses, } 0 \\
\text { included this term }\end{array}$ & \multirow{3}{*}{$\begin{array}{l}7 \text { of } 18 \text { Spanish licenses (39\%) } \\
3 \text { of } 18 \text { US licenses (17\%) }\end{array}$} \\
\hline & $\begin{array}{l}\text { Of the } 8 \text { university press licenses, } 3 \\
\text { included this term (38\%) }\end{array}$ & \\
\hline & $\begin{array}{l}\text { Of the } 16 \text { commercial publisher } \\
\text { licenses, } 7 \text { included this term (44\%) }\end{array}$ & \\
\hline
\end{tabular}

\section{Licensee Obligations Related to Security}

We also sought to ascertain what proportion of licenses included a clause requiring the licensee (library or university) to monitor for unauthorized use (see table 5). We were only able to achieve 72 percent intercoder reliability for this question, despite extensive training, suggesting that the license language in this area was especially vague. Keeping in mind the limitations of our ICR, our data point to an increase in the requirements that libraries monitor for unauthorized use, especially among academic press and society publishers. The earlier Rubel and Zhang study found 38 percent of licenses included this obligation, ${ }^{35}$ as opposed to 47 percent of our licenses. We also found that university press (63\%) and society press licenses $(50 \%)$ were more likely to include this clause than commercial publisher licenses (38\%).

We also looked to see the degree to which licenses obligated a library or its university to notify the publisher about breaches. Altogether, 69 percent of our licenses included a clause obligating libraries to notify the publisher (ICR 89\%). Discerning among publisher types, this study found the notification requirement was highest among commercial publishers $(88 \%)$, although it was common for university press (63\%) and society (50\%) publishers as well. Our overall lower proportion may be due to the higher number of university and society press publisher licenses included in our study.

Finally, we examined the degree to which licenses required libraries to take disciplinary action beyond notifying the publisher. We were unable to achieve our target intercoder reliability on this question (our ICR was 61\%), meaning readers should interpret these results with caution. We found that just 38 percent of our licenses included this obligation. However, considering only the post-2009 licenses in our study, the results rise to 40 percent, in line with the Rubel study. ${ }^{36}$ Our data, allowing us to distinguish between publisher types, show that university press publishers were much more likely to include this term than society or commercial publishers (63\% vs $40 \%$ and 38\%). Spanish university licenses were more likely to include this term than the US licenses (44\% vs 33\%). 
Our low intercoder reliability scores are an interesting finding in themselves because they indicate that the language in these security areas of licenses is particularly vague. While the vague license terms made it difficult for us to achieve our intercoder reliability targets, what was frustrating for us as researchers may be good for libraries. Hill and Minchew argue that vaguer language can increase library flexibility in responding to publishers when problems like breaches occur, while still allowing for local policies and procedures. ${ }^{37}$ Confusing and difficult-to-interpret terms about library security obligations may act as a buffer. Strategic ambiguity in a license can be helpful to library managers.

\begin{tabular}{|c|c|c|}
\hline \multicolumn{3}{|c|}{$\begin{array}{c}\text { TABLE } 5 \\
\text { Library Obligation in Case of Breach and Licenses by Type and Nation }\end{array}$} \\
\hline $\begin{array}{l}\text { License Contains Terms } \\
\text { Requiring Licensee to: }\end{array}$ & $\begin{array}{l}\text { Number by Publisher Type } \\
\text { Society: } 12 \\
\text { University: } 8 \\
\text { Commercial: } 16\end{array}$ & $\begin{array}{l}\text { Spanish }(n=18) \\
\text { US Licenses }(n=18)\end{array}$ \\
\hline $\begin{array}{l}\text { Q47: Notify publisher of } \\
\text { unauthorized use }\end{array}$ & $\begin{array}{l}\text { Of the } 12 \text { society press licenses, } 6 \text { included } \\
\text { this term (50\%) }\end{array}$ & \multirow[t]{2}{*}{$\begin{array}{l}13 \text { of } 18 \text { Spanish } \\
\text { licenses }(72 \%)\end{array}$} \\
\hline \multirow[t]{2}{*}{25 of 36 licenses (69\%) } & $\begin{array}{l}\text { Of the } 8 \text { university press licenses, } 5 \\
\text { included this term (63\%) }\end{array}$ & \\
\hline & \begin{tabular}{|l|} 
Of the 16 commercial publisher licenses, 14 \\
included this term (88\%)
\end{tabular} & $\begin{array}{l}12 \text { of } 18 \text { US licenses } \\
(67 \%)\end{array}$ \\
\hline \multirow[t]{2}{*}{$\begin{array}{l}\text { Q48: Monitor for unauthorized use } \\
\text { or other breach }\end{array}$} & $\begin{array}{l}\text { Of the } 12 \text { society press licenses, } 6 \text { included } \\
\text { this term (50\%) }\end{array}$ & \multirow{3}{*}{$\begin{array}{l}9 \text { of the } 18 \text { Spanish } \\
\text { licenses }(50 \%) \\
8 \text { of the } 18 \text { US licenses } \\
(44 \%)\end{array}$} \\
\hline & \begin{tabular}{|l|} 
Of the 8 university press publisher licenses, \\
5 included this term (63\%)
\end{tabular} & \\
\hline (only 72\% ICR) & $\begin{array}{l}\text { Of the } 16 \text { commercial publisher licenses, } 6 \\
\text { included this term (38\%) }\end{array}$ & \\
\hline \multirow{2}{*}{$\begin{array}{l}\text { Q49: Take disciplinary action(s), } \\
\text { other than notifying the publisher, } \\
\text { when becoming aware of any } \\
\text { unauthorized use. }\end{array}$} & $\begin{array}{l}\text { Of the } 12 \text { society press licenses, } 3 \text { included } \\
\text { this term (40\%) }\end{array}$ & \multirow{4}{*}{$\begin{array}{l}8 \text { of the } 18 \text { Spanish } \\
\text { licenses }(44 \%) \\
6 \text { of the } 18 \text { US licenses } \\
(33 \%)\end{array}$} \\
\hline & $\begin{array}{l}\text { Of the } 8 \text { university press licenses, } 5 \\
\text { included this term (63\%) }\end{array}$ & \\
\hline Only $61 \%$ ICR & $\begin{array}{l}\text { Of the } 16 \text { commercial publisher licenses, } 6 \\
\text { included this term (38\%) }\end{array}$ & \\
\hline & & \\
\hline
\end{tabular}

\section{Discussion}

To detect changes in licensing practice over time, we compared our findings to earlier licensing studies in addition to suggested terms in both the Liblicense and California Digital Library (CDL) model licenses. It should be underlined that our findings regarding such changes are limited by our data set: we attempted to obtain all newer licenses, and 20 of the 36 licenses were signed in 2014 or later; but our older licenses may not show all the newest language. This is a limitation of using "signed" licenses rather than simply analyzing publisher boilerplate terms. Arguably, the analysis of signed licenses would be a more valid representation of the terms to which libraries actually agree. This methodological tension shows that analysis of both signed licenses and boilerplate terms are important. 


\section{ILL Print Requirement}

Our results suggest the requirement that printing a paper copy be part of the ILL process ("print requirement") has fallen by the wayside over time. This change represents a positive trend from a licensing advocacy perspective. Both the Liblicense and CDL model license recommend that any signed license give librarians the freedom to fulfill the ILL request using the most appropriate mode, "using electronic, paper, or intermediated means." Librarians negotiating licenses that still include print requirements should evoke these results to argue that print requirements are not necessary and no longer a norm in the field.

\section{ILL Delivery to Commercial Users}

A comparison of our results to those of earlier work suggests no reduction in the proportion of licenses that restrict ILL to commercial users. This lack of change can be viewed negatively, as a lack of progress. Model licenses do not include terms specifically about commercial users, instead pointing to either Fair Use or CONTU guidelines that might allow for some delivery to commercial users. On the other hand, one can see the result as positive in that the proportion of licenses restricting ILL to commercial users has not increased. Negotiators should remain vigilant in trying to remove clauses that specifically restrict ILL to commercial users and instead insert clauses that refer to Fair Use or CONTU.

\section{E-reserves Deletion Requirement}

Our data show an increase in e-reserves deletion requirements compared to earlier studies, and the results stem primarily from society and university press publisher licenses. The recommended terms in both the CDL and the Liblicense model licenses avoid any mention of deletion of ILL materials; instead, they suggest language that allows electronic reserves if the materials are used "in connection with specific courses of instruction." Librarians negotiating licenses need to increase efforts to modify society and university press licenses to avoid mention of file deletion.

\section{Authors' Rights}

Both the Liblicense and CDL model licenses suggest terms to retain authors' rights for activities including self-archiving and depositing in repositories. But our results, and the results of related studies, show that few licenses include the recommended terms. This implies that licensing advocacy efforts in this area have not been very effective, at least for the two university libraries providing licenses. It could be that national or state policy initiatives to require open access copies such as Plan $S$ in Europe, or funder requirements for open access, may be more effective. Initiatives to promote open science, especially in Europe, make it even more important that authors of the subscribing institution maintain rights so that their works can be freely used for scientific and educational purposes. Librarians negotiating licenses could pay greater attention to the inclusion of these terms.

\section{Third-party Sharing of Usage Data}

We searched to find whether licenses contained terms or conditions about sharing any type of user data with third parties. Our findings show a lower proportion of licenses addressing third-party sharing clauses than earlier work; however, the decline reflected by our results may be due to the greater number of society publisher licenses in our sample. Society pub- 
lisher licenses were less likely to address third-party sharing. Model licenses recommend that user data should not be reused or sold to third parties without permission. Only two studies have reported on sharing clauses, so it is too early to claim that terms allowing sharing are becoming less common. Still, the results should encourage licensing librarians to advocate for removing terms that allow third-party sharing. License provisions related to data privacy are important, as Magi, ${ }^{38}$ Rubel, $^{39}$ and Rubel and Zhang ${ }^{40}$ discuss, since libraries may enter into contracts that conflict with values such as intellectual freedom and privacy. Licensing agreements that allow publishers to share data with third parties can create an avenue for patron privacy loss.

\section{Publisher's Right to Suspend Authorized Use}

Comparing our data with earlier studies reveals a growing proportion of licenses that include terms reserving publishers' rights to take action to terminate authorized users' access in the event of a breach. The CDL model license includes language permitting publisher termination of access but puts obligations back on the side of the Licensor to ensure that it will only take action to stop unauthorized use "which is causing serious and immediate material harm to the Licensor." Furthermore, the Licensor is obligated to ensure that any such suspensions are of "the shortest duration possible" and that the Licensor should immediately notify the library "of any such suspension, including the reason for the block and any supporting details." For breaches that do not meet that level of harm, the model licenses suggest that the licensor and licensee work together to address the breach and prevent reoccurrence. Librarians negotiating licenses should advocate for inclusion of the recommended, more limited terms, rather than more general permissions for publishers to block authorized users.

\section{Licensee Obligations Related to Security}

Our data suggest that it is common for licenses to include clauses requiring libraries to monitor for unauthorized use. Inclusion of this clause was most prominent among academic press and society publishers. Model licenses suggest much softer alternative language that limit the library's obligations to take "reasonable actions" to restrict access to authorized users. Model licenses do not include any terms suggesting that libraries undertake monitoring.

Our results point to a decrease in the proportion of licenses obligating libraries to notify publishers of breaches compared to earlier studies, but this decline may have to do with the number of university and society press licenses in our study. We found inclusion of this clause was most common among commercial publishers. Both model licenses suggest terms requiring libraries to notify publishers when they become aware of a breach, but both limit this obligation to situations where the library cannot immediately fix the situation - or "cannot promptly remedy it." Librarians negotiating licenses should seek to include these more limited terms suggested by model licenses instead of terms that require notification of all breaches, even those ameliorated quickly and locally. Tomas Lipinski, for example, argues that requiring licensees to report infringers conflicts with user privacy; a privacy-respecting alternative would be a milder provision that generally affirms that the licensee will help curb abuse. ${ }^{41}$ Likewise, licenses could provide libraries the option to address infractions themselves without reporting to the publisher. This, Lipinski maintains, provides the opportunity for libraries to address unauthorized use via teaching rather than sanction. ${ }^{42}$ 
We analyzed whether licenses obligate libraries to take disciplinary action beyond notifying the publisher when a breach occurs. Our results should be treated with caution because we were not able to meet our intercoder reliability score targets due to the license term vagueness in this area. Even given this limitation, we make two arguments. First, it is clear that some licenses include this obligation even though neither model license recommends terms that would obligate libraries to take disciplinary action. Licensing librarians should remove clauses that clearly include an obligation to take disciplinary action. A second important finding is that many licenses' terms in this area are confusing and difficult to interpret. These difficultto-interpret terms may be helpful in satisfying both parties during a negotiation. If a licensor insists, then the more ambiguous terms may be helpful as they provide library managers more flexibility in coping with breach situations.

Where our data show deviation from model license recommended language, one explanation would be that the power and expertise imbalance between libraries and publishers in license negotiators requires concessions. Every turn of a negotiation entails costs in time, effort, and goodwill; and inclusion of all the recommended terms in a license may be too costly in situations where libraries lack bargaining power. To get one desired term or price point, a library negotiator may have to make concessions.

In comparing our finding to model licenses, we found three instances where licenses did not include recommended terms for other reasons. This was the case for terms requiring the licensor to supply COUNTER-compliant usage statistics, terms explicitly permitting ereserves links, and terms allowing data mining. In each of the three cases, the model licenses suggest license terms for inclusion. But one explanation for the lack of inclusion of these recommended terms may be the belief that they do not need to be spelled out in the license because they are being taken care of elsewhere. It could be that law covers the issue, such as the argument that e-reserves linking from licensed resources is covered by Fair Use such that it does not need explicit permission. ${ }^{43}$ Alternatively, it could be that a separate pledge and monitoring system (like COUNTER registry) or a license addenda (for example, for data mining) effectively deals with the issue.

\section{International Differences}

Although generalizing or extrapolating our results is risky, given that the data were drawn from just two institutions, this study including non-North American licenses gives results that reveal noteworthy differences between US and Spanish licenses. For example, we found that Spanish licenses were more likely to contain international ILL restrictions than the US ones. It would be wise for future research to examine licenses from a wider array of international libraries to assess: to what degree national ILL restrictions are more common outside North America; and the potential impact of limitations on ideals of international ILL and international information flows. ${ }^{44}$ License negotiators should seek to eliminate the clauses that prevent ILL between different countries, something that goes against the tradition of noncommercial academic collaboration. These clauses are especially damaging for the institutions of small countries, where the number of academic institutions is lower and, therefore, it may be impossible to find the required work within national borders.

It is important to consider differences between the US and Spanish legal contexts and how they may bear an impact on license contents. The content of the licenses is designed by international publishers who tend to create uniform contracts that address the largest 
number of customers and that draw on law in the publisher's home nation. For example, the Spanish licenses we examined referred to US-specific terms such as Section 108 and CONTU Guidelines, and even US export restrictions for research related to encryption or munitions. Other Spanish licenses referred to UK-specific legislation. Interestingly, we did not encounter any terms or concepts from Spanish civil law in the contracts in our sample. The only Spanish-language license studied here contained a mere translation of the original English language. One possible explanation is that, due to the very large number of academic libraries in North America and the location of many publishers in the US/UK, other nations have to adapt to foreign terms and concepts optimized for libraries and laws in the US/UK. Further, LIS scholars have suggested that greater development of the professional copyright librarian ${ }^{45}$ or licensing librarian ${ }^{46}$ in the context of the US might give their institutions an advantage in negotiating terms, in detriment to library professionals in other nations. Future research will ideally take in a wider sample of non-North American signed licenses or include data on non-North American licensing librarians' experiences, to further explore these gray areas.

\section{Conclusion and Recommendations}

This study makes a dual contribution to the ongoing conversation about licenses and licensing practices. First, it includes licenses signed up to the year 2016. As highlighted in the 2017 IFLA licensing literature review, licensing terms change (indeed, licensing advocacy encourages this). Yakoleva's 2017 IFLA report urges the profession to continuously update its knowledge base about what terms licenses include and to track what licensing problems persist, which appear to have ameliorated. ${ }^{47}$ Claims made about licenses in the mid to late 2000s may be very different from new claims founded on the analysis of more recent licenses. If we want to monitor the effectiveness of licensing advocacy and education efforts (such as model licenses) we must be on the alert for changes in license terms over time. Second, the fact that this study included licenses from a Spanish university helps bring the spotlight on issues relevant to the non-US context. Most prior studies are focused exclusively on North American licensing practices.

Our results come to underline how important it is for licensing librarians to harbor an evolving knowledge of a broad array of emerging licensing issues. Granted, price is important; yet academic librarians should not always place the emphasis on negotiating prices. They should gain in awareness of the negative implications of certain clauses and make efforts to remove them, adapt them to the language suggested in model licenses, or at least ensure that the language is vague enough to allow for local flexibilities in decision making. Our data would encourage licensing librarians to seek modifications of the following license terms:

- Argue that print requirements are not necessary and no longer a norm in the field.

- Remove clauses that specifically restrict ILL to commercial users, and instead insert clauses that refer to Fair Use, CONTU, or the relevant national library reuse rights legislation.

- Avoid obligations to delete e-reserves files at the end of a term or class and instead use language referring to ongoing use of the file.

- Include authors' rights terms for self-archiving and deposit in repositories.

- Remove terms that allow sharing of use data with third parties without the explicit permission of the library. 
- Limit publisher rights to terminate access to cases of serious and immediate material harm. Ensure access is limited for the shortest duration possible, and require immediate notification of the library.

- Avoid language that obligates libraries to monitor for unauthorized use, replacing it with language requiring reasonable actions to restrict access to authorized users.

- Avoid language that obligates libraries to notify licensors of breaches, or limit notification requirements to situations where the library cannot promptly remedy the problem.

- Remove language obligating libraries to take disciplinary action when a breach occurs. Moreover, our results suggest broader discussion within the licensing community about the degree to which all information about a license should be retained in the license document.

- Should compliance with COUNTER usage standards be explicit in a license or is it acceptable to rely on third-party monitoring sites?

- Should e-reserves rights be explicit in a license or does it suffice to infer the rights from Fair Use, CONTU, or other national legislation?

- Should data mining terms be in licenses or managed via separate agreements?

This study illuminates a limitation of model licenses such as Liblicense or the CDL as an educational tool: they do not address every issue, leaving an information gap. Due to their role as contract templates and position statements, they do not address some controversial areas of licensing practice, nor can they provide explanation of alternatives surrounding suggested terms. For example, model licenses do not include suggested terms for library monitoring obligations. This is because the experts that created the model do not recommend any terms requiring monitoring. The model does not include language about monitoring because it does not recommend any monitoring. But the omission of the topic creates an information hole: Simply looking at the model license does not educate the licensing librarian about the problems associated with monitoring language they are likely to see in licenses. To impact licensing practice internationally, other free and accessible forms of licensing education, like an updated version of the IFLA E-Resource Development Guide, are needed. Ideally these resources would complement the guidance provided by model licenses, but they have the space to explain the pros and cons of different versions of objectionable terms and lay out an array of options from which librarians might choose, given local conditions and restrictions.

The international differences encountered in this study draw attention to a need to provide more support for libraries outside North America to take action to remove objectionable terms. Important work is being done through IFLA Copyright and Other Legal Matters interest group, but more is needed to increase capacity to get better terms, especially in situations of limited resources where transaction costs connected with negotiation aggravates the existing power differentials between publishers and libraries.

\section{Acknowledgments}

This study was supported by the Spanish Ministry of Economy and Competition (projects DER2014-53012-C2-2-R and PRX16/00327). 


\section{APPENDIX A. Codebook and Code Rules}

\section{Directions:}

Each column in the spreadsheet corresponds to an answer possibility. Mark 1 in each column when your answer to the question is "Yes," and mark " 0 " when your answer is "No" or is the opposite of the statement in the question.

General Coding rules that apply to all questions:

1. Any text about ILL and e-reserves should only be referred to in answers to questions specific to ILL and e-reserves.

2. Assume that "third party" means external, or nonauthorized users.

3. Mark at least one thing for each section...even if it is a best guess.

\section{Demographic Questions:}

1. Enter latest date found on licenses document (year only in 4-digit format). If there is no date information, mark 0 .

Note: There are licenses signed several years ago and then have been renovated with only price changes. These licenses are updated but the original date is older.

\section{DOWNLOADING}

Specific Rules for these questions:

a. The focus here is on individual scholarly/personal exchange. Any mention of ILL or e-reserves should NOT go here, commercial exchange/doc delivery not included here, republishing not included here;

b. prohibition on reproducing an entire issue count as "systematic" printing/downloading.

Does this license in any way limit downloading/saving of license content by authorized users? (Mark all that apply.)

2. Does not address below listed restrictions on downloading or saving.

3. Forbids systematic or automated downloading/saving, including that done by robots or intelligent agents.

4. Limits reproduction to personal use only (includes research, education, personal need, etc.)

\section{SCHOLARLY SHARING AND USE}

Rule specific to these questions: restrictions on posting to networks, including intranets and the internet, get coded as \#13 or \#14

Does this license in any way limit the electronic distribution of works by authorized users to other authorized users? (Mark all that apply.)

5. Does not describe any of the below limitations on internal e-distribution.

6. Prohibits any internal e-distribution.

7. Forbids any "systematic" e-distribution to internal users.

Does this license in any way limit the electronic distribution of works by authorized users to nonauthorized users? (Mark all that apply.)

8. Does not describe any of the below limitations on external e-distribution. 
9. Prohibits any external e-distribution.

10. Forbids any "systematic" e-distribution to external users.

11. E-distribution permitted to regulatory, patent, trademark agencies.

12. Limits e-distribution to "scholarly sharing" or similar term (assumes it is for the nonauthorized recipients' personal/research use only).

13. No posting on any networks at all, including licensee's secure networks.

14. Does not permit sending materials to a country where it is prohibited by US law or regulations.

Does this license in any way limit the use of licensed materials to perform and engage in text and/or data mining activities? (Mark all that apply.)

15. Does not describe any of the below limitations on text and/or data mining activities.

16. Prohibits any text and/or data mining activities.

17. Prohibits making the results of text and data mining available for use of others.

Does this license establish special conditions for authors who are authorized users of licensee in relation with their own works? (Mark all that apply.)

18. Does not include any terms or conditions on this issue.

The author retains the royalty-free right to use their work for scholarly and educational purposes, including self-archiving at:

19. His/her personal web pages.

20. Institutional repository.

21. Third-party repositories.

Does this license make provisions to diminish the rights and privileges of the licensee or authorized users with respect to any of the licensed materials? (Mark all that apply.)

22. Does not include any terms or conditions on this issue.

23. It includes provision stating that the license shall not restrict acts otherwise permitted under copyright law.

24. It includes a provision establishing that the license cannot impose additional restrictions over the content of the licensed materials that are in the public domain or have been issued under a Creative Commons or other open license.

\section{COURSE PACKS AND ELECTRONIC RESERVES}

Does this license allow works to be used in electronic reserves or course packs for credit courses? (Mark all that apply.) Note: I have added "course packs" because they are usually included together with "electronic reserve."

Rule for this question:

a. Ignore all references to providing Braille option for reserves.

25. Does not address any of the below-listed limitations on e-reserves and course packs.

26. E-reserves and course packs prohibited.

27. Allowed, and no specific limitations are described.

28. Requires posting of acknowledgment of source/citation.

29. Requires deletion of saved files at end of semester, end of course, or after use is complete. 
30. Permits a link to the article in the database.

31. Requires (explicit) a link to the article in the database or requires that a "hit" be registered.

\section{INTERLIBRARY LOAN}

Does this license allow use of the work in Interlibrary Loan? (Mark all that apply.)

Rules for this question:

a. Do not include references to individual scholarly sharing here-only official ILL done by the library.

b. Do not include limitations to "single copy" here - that is part of CONTU.

c. Do not include references to "replace library subscription" - part of CONTU.

32. Does not address any of the below-listed limitations on ILL.

33. ILL prohibited.

34. Printing is required as part of the ILL process, like before sending via fax, e-transmission, mail - or before giving document to patron.

35. "Secure e-transmission" technique listed as an option for transmission.

36. "Secure e-transmission" technique required for transmission.

37. No sending to commercial users/no commercial uses permitted, or file must only be used for purposes of research or private study.

38. Receiving institution (library) must delete received electronic copy immediately upon delivery to end user.

39. Receiving institution (library) must be located within the same country as the subscriber.

\section{PRIVACY}

40. The license contains terms specifying that the publisher will provide usage data to licensee.

Code rule: If your answer to $Q 41$ is "0," please mark "0" for $Q 42-Q 45$.

41. The license contains terms specifying that the usage data provided to the licensee should be COUNTER compliant.

Code rule: If your answer to $Q 42$ is " 1 ," please mark " 1 " for $Q 43$.

42. The license contains terms specifying that statistics provided by the publisher will be aggregate statistics.

Code rule: "Aggregate statistics" can be defined as any usage statistics that cannot be used to identify individual user.

Code rule: Data about "usage activity of (each) institution" is NOT aggregated data.

43. The license contains terms about the publisher sharing data with any third parties.

Code rule: "Sharing data" will NOT include publisher's data transferring to third party when it is acquired or merged by the third party.

Code rule: If your answer to $Q 44$ is " 0 ," please mark " 0 " for $Q 45$.

44. The license contains terms specifying that the third parties obtaining any data from the publisher will be required to comply with the confidentiality provisions of this license.

Code rule: This question is only applied to "data sharing" and does not include "data transferring," as specified in the first code rule in $Q 44$. 
45. License contains terms reserving right for publisher to suspend authorized user access based on failure to abide by license terms.

Code rule: If the license only includes terms to suspend access of IP address where the unauthorized occurred, then mark " 0 " for $Q 4$, and mark " 1 " for $Q 47$.

Code rule: Only when the suspension action is conducted by the publisher, we should mark "1" for $Q 46$. Therefore, if the license states that the publisher requires the licensee to suspend authorized users' access due to their unauthorized use, then we should mark " 0 " for Q46, because it is the licensee, rather than the publisher, to suspend the access.

46. License contains terms reserving right for publisher to suspend access of the IP address(es) from which the unauthorized use occurred.

47. License contains terms requiring licensee to notify publisher of unauthorized use and/or copyright infringement.

48. License contains terms requiring licensee to monitor for any unauthorized use or other breach.

Code rule: If the license states that the licensee will monitor usage of the licensed materials for compliance with the terms of this licensee, then we should mark " 1 " for $Q 49$.

49. License contains terms requiring licensee to take disciplinary action(s), other than notifying the publisher, when becoming aware of any unauthorized use.

\section{GOVERNING LAW AND VENUE}

50. The license will be governed by the national law of the subscriber.

51. The license will be governed by the national law of the publisher.

52. Any controversy or claim shall be brought in the courts of subscriber's country.

53. Any controversy or claim shall be brought in the courts of publisher's country.

54. It includes an arbitration clause. 


\section{APPENDIX B. Licenses by Publisher, Type, and Year}

\begin{tabular}{|l|l|l|}
\hline Society Publishers: 6 publishers and 12 licenses & US year of license & Spain year of license \\
\hline American Association for Cancer Research & $2005^{*}$ & 2014 \\
\hline American Medical Association & 2013 & 2014 \\
\hline American Physical Society & 2016 & 2015 \\
\hline American Society of Civil Engineers (ASCE) & 2011 & 2017 \\
\hline American Society of Mechanical Engineers (ASME) & 2011 & 2015 \\
\hline Royal Society of Chemistry “Current Access" & $\begin{array}{l}2013 \text { partial license } \\
\text { supplemented by } \\
\text { boilerplate license }\end{array}$ & 2012 \\
\hline University Press: 4 publishers and 8 licenses & \multicolumn{2}{|l|}{} \\
\hline Cambridge University Press & 2012 & 2010 \\
\hline Duke University Press & 2010 & $2008^{*}$ \\
\hline Oxford University Press & $1999^{*}$ & 2015 \\
\hline University of Chicago & $2000^{*}$ & 2017 \\
\hline Commercial Publisher: 8 publishers and 16 licenses & 2011 \\
\hline CAIRN & 2011 & 2015 \\
\hline Elsevier & 2016 boilerplate license & 2015 \\
\hline HEIN & 2014 & 2010 \\
\hline Kluwer & $\begin{array}{l}2016 \text { incomplete license } \\
\text { supplemented by } \\
\text { boilerplate license }\end{array}$ & $2002^{*}$ \\
\hline Sage & 2014 & 2013 \\
\hline Springer & 2014 & 2014 \\
\hline Taylor and Francis & 2018 boilerplate license \\
\hline Wiley & 2015 & 2 \\
\hline
\end{tabular}

*Supplemented by newer terms available on publisher websites.

\section{Notes}

1. Mark A. Lemley, "Beyond Preemption: The Law and Policy of Intellectual Property Licensing," California Law Review 40, no. 1 (1999): 111-72, https://doi.org/10.15779/Z38D146; Lucie Guibault, Copyright Limitations and Contracts: An Analysis of the Contractual Overridability of Limitations on Copyright (The Hague, Netherlands: Kluwer Law International, 2002); Philippa Davies, "Access v Contract: Competing Freedoms in the Context of Copyright Limitations and Exceptions for Libraries," European Intellectual Property Review 35, no. 7 (2013): 402-14; D.R. Jones, "Locked Collections: Copyright and the Future of Research Support," Law Library Journal 105, no. 4 (2013): 425-60.

2. Kristin R. Eschenfelder et al., "How Institutionalized Are Model License Use Terms: An Analysis of EJournal License Use Rights Clauses from 2000-2009," College and Research Libraries 74, no. 4 (2013): 326-55, https:// doi.org/10.5860/crl-289.

3. California Digital Library Standard License Agreement, available online at https://www.cdlib.org/cdlinfo/2017/01/25/cdl-model-license-revised/ [accessed 20 January 2020]; Liblicense Model License Agreement with Commentary (revised November 2014), available online at http://liblicense.crl.edu/wp-content/uploads/2015/05/ modellicensenew2014revmay2015.pdf [accessed 20 February 2020].

4. Vincent Larivière, Stefanie Haustein, and Philippe Mongeon, "The Oligopoly of Academic Publishers in 
the Digital Era," PLoS ONE 10, no. 6 (2015): e0127502, https://doi.org/10.1371/journal.pone.0127502.

5. David R. Hansen, William M. Cross, and Phillip M. Edwards, "Copyright Policy and Practice in Electronic Reserves among ARL Libraries," College and Research Libraries 74, no. 1 (2013): 69-84, https://doi.org/10.5860/crl313.

6. Eschenfelder et al., "How Institutionalized Are Model License Use Terms."

7. Kurt Munson, "Herding Cats: Challenges in Interlibrary Loan Lending of E-Journal Articles," Journal of Interlibrary Loan, Document Delivery \& Electronic Reserve 22, no. 3/4 (2012): 163-73, https://doi.org/10.1080/107230 3X.2012.719599.

8. Karen Okamoto, "Licensed to Share: How Libraries Are Handling Electronic Journal Article Requests," Journal of Interlibrary Loan, Document Delivery \& Electronic Reserve 22, no. 3/4 (2012): 137-54, https://doi.org/10.108 0/1072303X.2012.717494.

9. Lynn N. Wiley, "License to Deny? Publisher Restrictions on Document Delivery from E-Licensed Journals," Interlending \& Document Supply 32, no. 2 (2004): 94-102, https://doi.org/10.1108/02641610410538559.

10. Selden Durgom Lamoureux and James Stemper, "White Paper: Trends in Licensing," Research Library Issues: A Quarterly Report from ARL, CNI, and SPARC, no. 275 (2011): 19-24, https://doi.org/10.29242/rli.275.4.

11. Robert Tiessen, "How Copyright Affects Interlibrary Loan and Electronic Resources in Canada," Interlending \& Document Supply 40, no. 1 (2012): 49-54, https://doi.org/10.1108/02641611211214297.

12. Eschenfelder et al., "How Institutionalized Are Model License Use Terms."

13. Andrée J. Rathemacher, "Developing Issues in Licensing: Text Mining, MOOCs, and More," Serials Review 39, no. 3 (2013): 205-10, https://doi.org/10.1080/00987913.2013.10766397; Leslie A. Williams et al., "Negotiating a Text Mining License for Faculty Researchers," Information Technology and Libraries 33, no. 3 (2014): 5-21, https://doi. org/10.6017/ital.v33i3.5485; Megan Senseney et al., "Data Mining Research with In-copyright and Use-limited Text Datasets: Preliminary Findings from a Systematic Literature Review and Stakeholder Interviews," presentation at the 13th International Digital Curation Conference, Barcelona, Spain, February 19-22, 2018, available online at https://www.ideals.illinois.edu/handle/2142/99026 [accessed 20 February 2020].

14. Paul Grewal and Kirsten Huhn, "Text \& Data Mining Clauses in Academic Library Licenses: A Case Study," paper presented at the Concordia University Libraries' 14th Annual Research Forum, Montreal, April 29th 2016, available online at http://library.concordia.ca/about/staff/forum/files/Presentation_Grewal_Huhn.pdf [accessed 20 February 2020].

15. Jennifer Chan, Roxanne Peck, and Angela Riggio, "Negotiating Walled Gardens and Digital Playgrounds: Libraries and the World of Licensing for Text and Data Mining," panel discussion at Electronic Resources and Libraries Conference, Austin, TX, April 2-5, 2017, available online at https://www.electroniclibrarian.org/pastconferences/past-conferences-2017/2017-presentation-files/ [accessed 20 February 2020].

16. Ellen Duranceau and Ivy Anderson, "Author-Rights Language in Library Content Licenses," Research Library Issues: A Bimonthly Report from ARL, CNI, and SPARC, no. 263, 33-37, available online at https://publications.arl.org/rli263/34 [accessed 20 February 2020]; Birgit Schmidt and Kathleen Shearer, "Licensing Revisited: Open Access Clauses in Practice," Liber Quarterly 22, no. 3 (2012): 176-89, http://doi.org/10.18352/lq.8055; Stephen Buck, "Role of Library's Subscription Licenses in Promoting Open Access to Scientific Research," presentation at the Second KAUST Library Saudi Seminar, Thuwal, Saudi Arabia, April 29-30, 2018, available online at https:// repository.kaust.edu.sa/handle/10754/627730 [accessed 20 February 2020].

17. Arvind Kumar Singh and Bhaskar Mukherjee, "Electronic Information Resource Optimisation in Academic Libraries: A Comparative Study on Licensing Provision of Commercial Publisher," DESIDOC Journal of Library \& Information Technology 38, no. 3 (2018): 213-20, https://doi.org/10.14429/djlit.38.3.12468.

18. Alan Rubel and Mei Zhang, "Four Facets of Privacy and Intellectual Freedom in Licensing Contracts for Electronic Journals," College \& Research Libraries 76, no. 4 (2015): 427-49, https://doi.org/10.5860/crl.76.4.427.

19. Claire Dygert and Jeanne M. Langendorfer, "Fundamentals of E-Resource Licensing," Serials Librarian 66, no. 1/4 (2014): 289-97, https://doi.org/10.1080/0361526X.2014.881236; Claire Dygert and Robert Van Rennes, "Building Your Licensing and Negotiation Skills Toolkit," Serials Librarian 68, no. 1/4 (2015): 17-25, https://doi.or g/10.1080/0361526X.2015.1013384; Claire Dygert and Heather Barrett, "Building Your Licensing and Negotiation Skills Toolkit," Serials Librarian 70, no. 1/4 (2016): 333-42, https://doi.org/10.1080/0361526X.2015.1013384.

20. Trina J. Magi, "A Content Analysis of Library Vendor Privacy Policies: Do They Meet Our Standards?" College \& Research Libraries 71, no 3 (2010): 254-272, https://doi.org/10.5860/0710254

21. Rubel and Zhang, "Four Facets of Privacy and Intellectual Freedom in Licensing Contracts for Electronic Journals," 439.

22. Rubel and Zhang, "Four Facets of Privacy and Intellectual Freedom in Licensing Contracts for Electronic Journals," 437.

23. Eschenfelder et al., “How Institutionalized Are Model License Use Terms”; Rubel and Zhang, "Four Facets 
of Privacy and Intellectual Freedom in Licensing Contracts for Electronic Journals."

24. Eschenfelder et al., "How Institutionalized Are Model License Use Terms."

25. Eschenfelder et al., "How Institutionalized Are Model License Use Terms," 342.

26. Eschenfelder et al., "How Institutionalized Are Model License Use Terms," 340.

27. Grewal and Huhn, "Text \& Data Mining Clauses in Academic Library Licenses."

28. European Union, Directive (EU) 2019/790 of the European Parliament and of the Council of 17 April 2019 on copyright and related rights in the Digital Single Market and amending Directives 96/9/EC and 2001/29/EC, available online at https://eur-lex.europa.eu/legal-content/EN/TXT/PDF/?uri=CELEX:32019L0790\&from=EN [accessed 20 February 2020].

29. Singh and Mukherjee, "Electronic Information Resource Optimisation in Academic Libraries."

30. Rubel and Zhang, "Four Facets of Privacy and Intellectual Freedom in Licensing Contracts for Electronic Journals."

31. Tomas A. Lipinski, The Librarian's Legal Companion for Licensing Information Resources and Services (Chicago, IL: American Library Association, 2013), 615.

32. Sharon Johnson, with Ole Gunnar Evensen et al., "Key Issues for E-Resource Collection Development: A Guide for Libraries," available online at https://www.ifla.org/files/assets/acquisition-collection-development/ publications/Electronic-resource-guide.pdf [accessed 20 February 2020].

33. Rubel and Zhang, "Four Facets of Privacy and Intellectual Freedom in Licensing Contracts for Electronic Journals."

34. Rubel and Zhang, "Four Facets of Privacy and Intellectual Freedom in Licensing Contracts for Electronic Journals," 437.

35. Rubel and Zhang, "Four Facets of Privacy and Intellectual Freedom in Licensing Contracts for Electronic Journals," 437.

36. Alan Rubel, "Libraries, Electronic Resources, and Privacy: The Case for Positive Intellectual Freedom," Library Quarterly 84, no. 2 (2014): 183-208, https://doi.org/10.1086/675331.

37. Kate Hill and Tessa Minchew, "Into the Great Wide Open: Licensing, Vendor Relations and Security in Interesting Times," presentation at Electronic Resources and Libraries Conference, Austin, TX, March 24-27, 2018, available online at www.electroniclibrarian.org/past-conferences/past-conferences-2018/ [accessed 20 February 2020].

38. Magi, "A Content Analysis of Library Vendor Privacy Policies."

39. Rubel, "Libraries, Electronic Resources, and Privacy."

40. Rubel and Zhang, "Four Facets of Privacy and Intellectual Freedom in Licensing Contracts for Electronic Journals."

41. Lipinski, The Librarian's Legal Companion for Licensing Information Resources and Services, 448.

42. Lipinski, The Librarian's Legal Companion for Licensing Information Resources and Services, 451.

43. Hansen et al., "Copyright Policy and Practice in Electronic Reserves among ARL Libraries."

44. IFLA Licensing Principles (2001), available online at https://www.ifla.org/publications/ifla-licensingprinciples-2001 [accessed 20 January 2020]; A.K. Beaubien, et al., "White Paper: International Library Loan," Research Library Issues: A Quarterly Report from ARL, CNI, and SPARC, no. 275 (2011): 7-14, https://doi.org/10.29242/ rli.275.2.

45. Dick Kawooya, Amber Veverka, and Tomas Lipinski, "The Copyright Librarian: A Study of Advertising Trends for the Period 2006-2013," Journal of Academic Librarianship 43, no. 3 (2015): 341-49, https://doi.org/10.1016/j. acalib.2015.02.011.

46. Xiaohua Zhu, "Driven Adaptation: A Grounded Theory Study of Licensing Electronic Resources," Library $\mathcal{E}$ Information Science Research 38, no. 1 (2016): 69-80, https://doi.org/10.1016/j.lisr.2016.02.002.

47. Svetlana Yakovleva, "Literature Review on the Use of Licenses in Library Context, and the Limitations This Creates to Access to Knowledge," (2017), available online at https://www.ifla.org/files/assets/clm/statements/ limits_of_licensing_literature_review.pdf [accessed 20 February 2020]. 